\title{
Characterization of Brachiaria humidicola cv. BRS Tupi
}

\section{Caracterização da Brachiaria humidicola cv. BRS Tupi}

\author{
Maria Lindomárcia Leonardo da Costa ${ }^{1}$; Guilherme Rocha Moreira ${ }^{2}$; Ariosvaldo \\ Nunes de Medeiros ${ }^{1}$; Marilânia da Silva Santos ${ }^{3}$; Luana Magna de Souza ${ }^{3}$; Rodrigo \\ Amorim Barbosa ${ }^{4}$; Moacyr Cunha Filho ${ }^{2}$; Patrícia Guimarães Pimentel ${ }^{5}$; Frank \\ Gomes-Silva $^{2 *}$; Denise Stéphanie de Almeida Ferreira ${ }^{6}$
}

\begin{abstract}
This study aimed to carry out the morphogenic, structural, and bromatological characterization of Brachiaria humidicola cv. BRS Tupi. A completely randomized design was adopted. The treatments consisted of harvesting the forage at $14,28,42$, and 56 days. Leaf appearance rate, leaf elongation rate, and phyllochron were similar among the treatments $(\mathrm{P}>0.05)$. However, leaf life span varied among treatments $(\mathrm{P}<0.05)$. Dry matter exhibited linear behavior $(\mathrm{P}<0.05)$ whereas mineral matter, crude protein, neutral detergent fiber, acid detergent fiber, and lignin had quadratic behavior. Brachiaria humidicola $\mathrm{cv}$. BRS Tupi exhibits the best forage potential for animal feed between 28 and 42 days of growth.
\end{abstract}

Key words: Chemical composition. Forage. Morphogenesis.

\section{Resumo}

O objetivo desse trabalho foi a caracterização morfogênica, estrutural e bromatológica da Brachiaria humidicola cv. BRS Tupi. Adotou-se o delineamento inteiramente casualizado. Os tratamentos consistiram de diferentes idades de corte 14, 28, 42 e 56 dias. A taxa de aparecimento foliar, taxa de alongamento foliar e filocrono foram semelhantes entre os tratamentos $(P>0,05)$. Entretanto a duração de vida da folha variou entre os tratamentos $(\mathrm{P}<0,05)$. A matéria seca apresentou comportamento linear $(\mathrm{P}<0,05)$. Enquanto que material mineral, proteína bruta, fibra em detergente neutro e fibra em detergente ácido e lignina apresentaram comportamento quadrático $(\mathrm{P}<0,05)$. A Brachiaria humidicola cv. BRS Tupi apresenta melhor potencial forrageiro para alimentação animal entre 28 e 42 dias de crescimento.

Palavras-chave: Composição química. Forragem. Morfogênese.

\footnotetext{
1 Profs., Departamento de Zootecnia, Universidade Federal da Paraíba, UFPB, Areia, PB, Brasil. E-mail: lindomarciacosta@ gmail.com; ariosvaldo.medeiros@gmail.com

2 Profs., Programa de Pós-Graduação em Biometria e Estatística Aplicada, Universidade Federal Rural de Pernambuco, UFRPE, Recife, PE, Brasil. E-mail: guirocham@gmail.com; moacyr.cunhafo@ufrpe.br; franksinatrags@gmail.com

3 Discentes, Programa de Pós-Graduação em Zootecnia, UFPB, Areia, PB, Brasil. E-mail: marilania.santos@bol.com.br; luanna. magna7@gmail.com

4 Pesquisador, Empresa Brasileira de Pesquisa Agropecuária, EMBRAPA Gado de Corte, Campo Grande, MS, Brasil. E-mail: rodrigo.barbosa@embrapa.br

5 Prof ${ }^{\mathrm{a}}$, Departamento de Zootecnia, Universidade Federal do Ceará, UFC, Ceará, CE, Brasil. E-mail: pgpimentel@hotmail.com

6 Discente, Programa de Pós-Graduação em Biometria e Estatística Aplicada, UFRPE, Recife, PE, Brasil. E-mail: deniialmeida@ gmail.com

* Author for correspondence
} 


\section{Introduction}

Plants that make up grazing areas, or forage plants, are those consumed by animals for their development and reproduction. Successful forage plants are those that have evolved mechanisms to avoid overgrazing and predators, besides having adapted to appropriate edaphoclimatic conditions for their survival and dispersion. This type of strategy has required constant exposure to herbivores and, perhaps for that reason, African grasses, such as those of the genera Panicum, Brachiaria, and Pennisetum, are the most commonly employed to create pastures in tropical areas (Valle, Jank, \& Resende, 2009).

Brachiaria grasses have accounted for the development of animal husbandry in tropical and subtropical regions due to their adaptation to weak, acidic soils. Brachiaria brizantha, Brachiaria decumbens, Brachiaria ruziziensis, and Brachiaria humidicola are some of the most widely used species (Valle et al., 2009; Chiari, Rocha, Valle, \& Salgado, 2008).

Brachiaria humidicola, popularly known as koronivia grass, exhibits decumbent growth with rapid rooting. It is adapted to acidic, low-fertility soils and tolerates spittlebugs (Valle, Macedo, Euclides, Jank, \& Resende, 2010).

Cultivar BRS Tupi is the result of mass selection of Brachiaria humidicola populations collected in Burundi, eastern Africa, by the CIAT (International Center for Tropical Agriculture), headquartered in Colombia. Selection works took 18 years and were coordinated by Embrapa Beef Cattle in partnership with Embrapa Acre, Embrapa Eastern Amazon, Embrapa Cerrados, the State University of Maringá, and the Executive Commission of the Cacaueira plan (CEPLAC-CEPEC) in the Brazilian state of Bahia. The cultivar was selected based on its productivity, vigor, seed production, support capacity, and animal performance. BRS Tupi was registered at the Brazilian ministry of agriculture in May 2004 and was awarded the certificate of protected cultivar in
July 2009 (Associação para o Fomento à Pesquisa de Melhoramento de Forrageiras [Unipasto], 2019).

This study aimed to carry out the morphogenic, structural, and bromatological characterization of Brachiaria humidicola cv. BRS Tupi at different ages.

\section{Material and Methods}

Site

The trial was carried out at the vegetation house at the Department of Soils of the Center of Agrarian Sciences (CCA) of the Federal University of Paraíba (UFPB), located in the municipality of Areia, microregion of Brejo Paraibano, at $06^{\circ} 57^{\prime}$ $48^{\prime}$ S, $35^{\circ} 41^{\prime} 30$ " $\mathrm{W}$, and $618 \mathrm{~m}$ altitude.

\section{Plating}

Soil was collected at about $20 \mathrm{~cm}$ deep into the tillable layer, sieved in $6 \mathrm{~mm}$ mesh, and air dried. The soil had loamy-clayey-sandy texture and $\mathrm{pH}$ 4.7 in water, with chemical composition of $2.8 \mathrm{mg} /$ $\mathrm{dm}^{3} \mathrm{P}, 0.118 \mathrm{cmol} / \mathrm{dm}^{3} \mathrm{~K}, 1.4 \mathrm{cmol}_{\mathrm{c}} / \mathrm{dm}^{3} \mathrm{Ca}, 1.2$ $\mathrm{cmol}_{\mathrm{c}} / \mathrm{dm}^{3} \mathrm{Mg}$, sum of bases of $2.71 \mathrm{cmol}_{\mathrm{c}} / \mathrm{dm}^{3}$, $0.77 \mathrm{cmol}_{\mathrm{c}} / \mathrm{dm}^{3} \mathrm{Al}, \mathrm{H}+\mathrm{Al} 7.2 \mathrm{cmol}_{\mathrm{c}} / \mathrm{dm}^{3}$, cation exchange capacity of $9.91 \mathrm{cmol}_{\mathrm{c}} / \mathrm{dm}^{3}$, and $27.34 \%$ base saturation. Acidity was corrected with calcitic lime application $(\mathrm{ENV}=72.14 \%)$. The soil was added to 20 vases with $0.071 \mathrm{~m}^{2}$ each and seeding was carried out eight days later in four pits with five seeds each.

\section{Management}

Twenty days after emergence, culling was performed to maintain four plants per vase. Initial fertilization consisted of the application of $250.7 \mathrm{~kg}$ $\mathrm{N} / \mathrm{ha}, 249.29 \mathrm{kgP} / \mathrm{ha}$, and $84.5 \mathrm{~kg} \mathrm{~K} / \mathrm{ha}$. Water control was performed daily so that the soil/vase systems maintained $100 \%$ of their field capacity. Twentyeight days after emergence, a standardization cut was carried out $10 \mathrm{~cm}$ above the soil. 


\section{Measuring morphogenic and structural characteristics}

A ruler was used every three days to measure the morphogenic and structural characteristics of two shoots previously tagged with satin ribbons of distinct colors from different plants in each vase.

Leaf appearance rate (LAR), leaf elongation rate (LER), phyllochron, and leaf life span were assessed according to the methodology adopted by Santos, Sales and Costa (2007). Final leaf length and the number of living leaves were determined using the methodology employed by Sales et al. (2014).

\section{Bromatological composition}

In order to determine bromatological composition, the plants were pre-dried in a forcedair oven at $55^{\circ} \mathrm{C}$ for $72 \mathrm{~h}$, ground in $1 \mathrm{~mm}$ mesh, and stored in airtight polyethylene vials. Dry matter (DM), mineral matter (MM), and crude protein (CP) were determined using the Kjeldahl method according to the Association of Offcial Analytical Chemists [AOAC] (1990) while neutral detergent fiber (NDF), acid detergent fiver (ADF), and lignin were determined using the technique described by Van Soest, Robertson and Lewis (1991).

\section{Statistics}

The trial followed a completely randomized statistical design. The treatments consisted of harvesting the forage at $14,28,42$, and 56 days after the standardization cut with five replicates (vases per treatment). The data were submitted to normality and homoscedasticity analyses using Lilliefors and Bartlett's tests, respectively.

Bromatological composition was analyzed using analysis of variance and, since the treatments were quantitative, they were analyzed using linear and quadratic regressions and deviation according to Fisher's test $(\mathrm{P}<0.05)$.

The morphogenic and structural measures showed no normal distribution or homogeneous variances and were assessed by Kruskal-Wallis test with Dunn's post-hoc test application.

\section{Results and Discussion}

\section{Morphogenic and Structural Characteristics}

The present research found no differences $(\mathrm{P}>0.05)$ in LAR (Table 1). Higher LAR values mean higher percentages of leaves and lower percentages of dead material, i.e., greater forage availability for animal feed (Martins, Euclides, \& Barbosa, 2013).

The increase in LER can be attributed, in addition to the species, to appropriate conditions of water, light, nutrients, and temperature throughout the trial (Silva, Andrade, \& Magalhães, 2015). Although the present research found no differences for this characteristic, the result was similar to the one reported by Camara (2013), who reported 0.461 shoot $^{-1}$ day $^{-1}$ for Brachiaria humidicola cv. BRS Tupi at 28 days old.

Table 1

Morphogenic characteristics of Brachiaria humidicola cv. BRS Tupi at different ages

\begin{tabular}{|c|c|c|c|c|}
\hline Age (days) & LAR (leaves shoot ${ }^{-1}$ day $^{-1}$ ) & LER $\left(\mathrm{cm} \mathrm{shoot}^{-1}\right.$ day $\left.^{-1}\right)$ & Phyllochron (leaves day ${ }^{-1}$ ) & Leaf life span (days) \\
\hline 14 & $0.18(0.14-0.28)$ & $0.460(0.00-1.00)$ & $5.8(3.50-7.00)$ & 9.84 c (7.33-11.50) \\
\hline 28 & $0.23(0.10-0.28)$ & $0.460(0.00-0.87)$ & $4.3(3.50-9.33)$ & $16.19 \mathrm{~b}(14.27-19.80)$ \\
\hline 42 & $0.21(0.11-0.28)$ & $0.405(0.32-0.51)$ & $4.7(3.50-8.40)$ & $24.91 \mathrm{ab}(22.93-29.92)$ \\
\hline 56 & $0.14(0.01-0.26)$ & $0.580(0.31-0.79)$ & $7.0(3.70-14.00)$ & $37.96 \mathrm{a}(33.88-43.50)$ \\
\hline
\end{tabular}

Different letters in the columns indicate difference according to Friedman test $(\mathrm{P}<0.05)$ with application of Dunn's post-hoc test $(\mathrm{P}<0.05)$. LAR - leaf appearance rate, LER - leaf elongation rate. 
Leaf life span was longer $(\mathrm{P}<0.05)$ at 56 days when compared to initial ages (14 and 28 days). This characteristic is used as a criterion in management to maximize forage accumulation, prevent losses due to senescence and damages to the forage canopy structure so as to maximize yield in terms of animal/ area, and ensure pasture stability (Gomide, Gomide, $\&$ Paciullo, 2006). This characteristic must be taken into account when establishing cutting intervals since longer leaf life span enables longer intervals (Silva et al., 2009).

The highest number of living leaves $(\mathrm{P}<0.05)$ was found at 42 days (Table 2). Silveira (2006), when working with $\mathrm{cv}$. BRS Tupi under free growth, found values of 8.0 leaves shoot ${ }^{-1}$ day $^{-1}$.

The number of leaves in the shoot is an important reference of the shoot potential since each axillary bud associated with a leaf may determine a new shoot and, thus, may change the structural characteristics of the forage. Both the cutting interval and nitrogen are major factors to change the number of green leaves in a shoot (Maranhão et al., 2010). Since the leaf is the part of the plant with the greatest contribution to the photosynthesis process, growth physiology is geared towards its development, as shown by Martins et al. (2013), who reported a large percentage of leaves.

Table 2

Structural characteristics of Brachiaria humidicola cv. BRS Tupi at different ages

\begin{tabular}{|c|c|c|}
\hline Age (days) & Number of living leaves (leaves shoot ${ }^{-1}$ day $^{-1}$ ) & Leaf final length $\left(\mathrm{cm} \mathrm{shoot}^{-1}\right.$ day $\left.^{-1}\right)$ \\
\hline 14 & $5.50 \mathrm{~b}(4.00-7.00)$ & $7.44(3.58-9.88)$ \\
\hline 28 & $10.00 \mathrm{ab}(5.00-12.00)$ & $7.35(4.93-9.82)$ \\
\hline 42 & $12.50 \mathrm{a}(7.00-17.00)$ & $5.70(4.69-7.90)$ \\
\hline 56 & $8.50 \mathrm{ab}(4.00-18.00)$ & $10.44(5.97-20.33)$ \\
\hline
\end{tabular}

Different letters in the columns indicate difference according to Friedman test $(\mathrm{P}<0.05)$ with application of Dunn's post-hoc test $(\mathrm{P}<0.05)$.

\section{Bromatological composition}

DM content increased linearly with plant age (Figure 1). According to Oliveira et al. (2000), the continuous increase in DM yield is associated with the growing proportion of stem in grass biomass since, as the forage plant develops, the proportion of leaves progressively decreases as stem elongation intensifies, which leads to marked weight gain of the shoot and, consequently, of forage yield. 


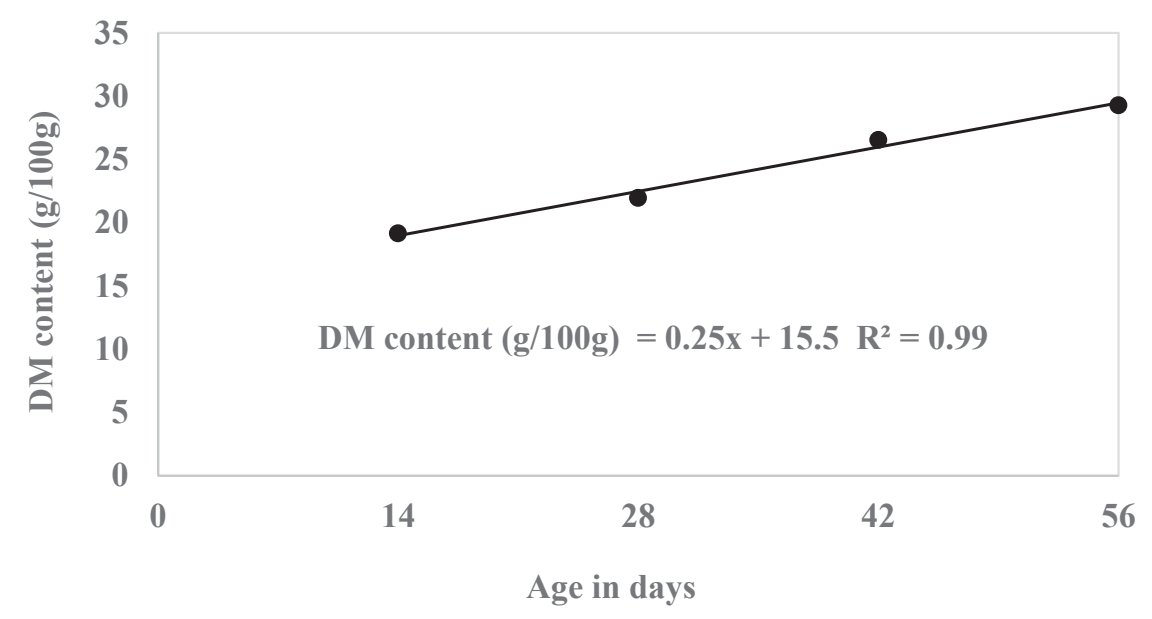

Figure 1. DM content of Brachiaria humidicola cv. BRS Tupi.

MM concentration decreased to the lowest level $(5.12 \mathrm{~g} / 100 \mathrm{~g})$ at 50 days (Figure 2). The mineral composition of forage plants varies as a function of interdependent factors such as plant age, soil fertility (fertilizing), differences among species and varieties, and season, among others (Cezário, Ribeiro, Santos, Valadares, \& Pereira, 2015; Leal et al., 2016).

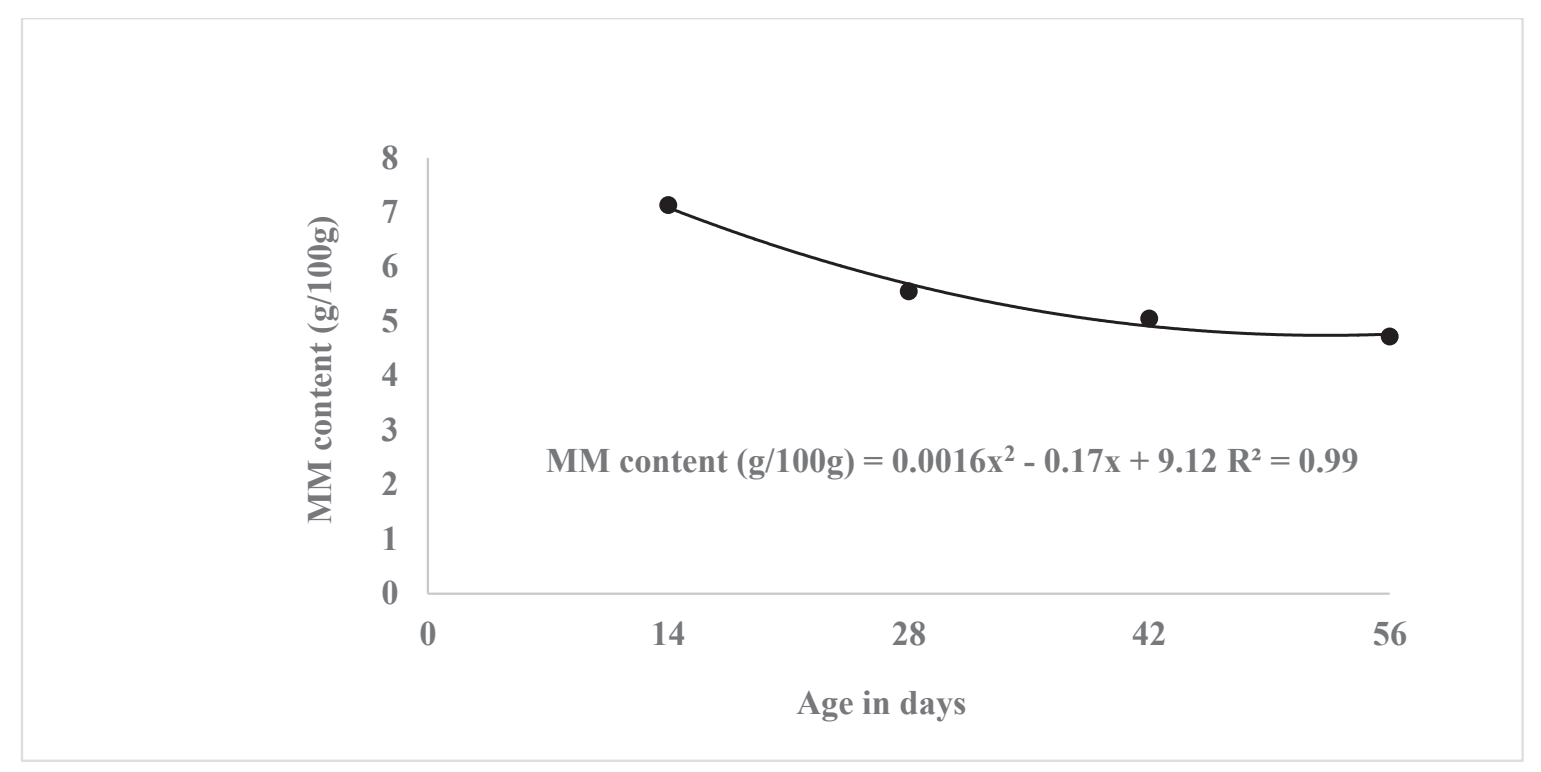

Figure 2. MM content of Brachiaria humidicola cv. BRS Tupi.

As the forage plants matured, a quadratic reduction was observed (lowest point at 51.31 days and concentration of $6.25 \mathrm{~g} / 100 \mathrm{~g}$ ) in $\mathrm{CP}$ content (Figure 3). According to Van Soest (1994), that is explained by the decrease in cell content, whereas the high CP content at 14 days of age is related to the initial vegetative growth stage of the forage plant. The values found in the present study at 30 days 
(11.74 g/100 g) match those by Leal et al. (2016), and spring. Those authors reported CP contents of who assessed the nutritional value of BRS Tupi cut in 30-day intervals in summer, autumn, winter,

$8.79,8.31,8.71$, and $10.6 \mathrm{~g} / 100 \mathrm{~g}$, respectively, i.e., higher age at cut led to lower $\mathrm{CP}$ contents.

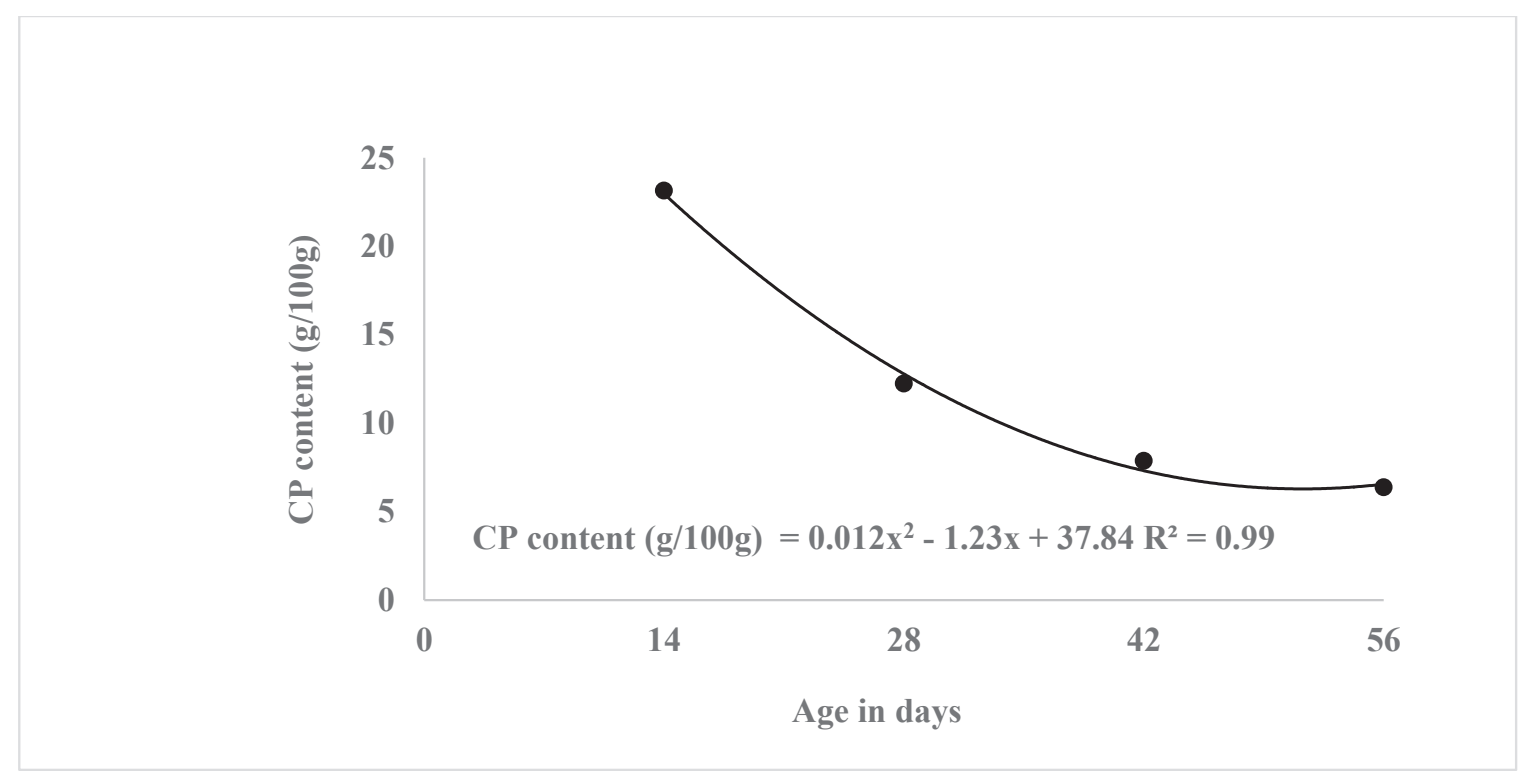

Figure 3. CP content of Brachiaria humidicola cv. BRS Tupi.

The NDF fraction increased until 55.84 days to reach concentration of $75.95 \mathrm{~g} / 100 \mathrm{~g}$. This result was expected due to the increase in cell wall components. NDF is a major parameter in defining forage quality and limits the intake capacity of animals (Costa et al., 2007). Hence, forage plants harvested at more advanced ages will be less consumed and digestible by animals (Jung \& Allen, 1995; Leal et al., 2016).

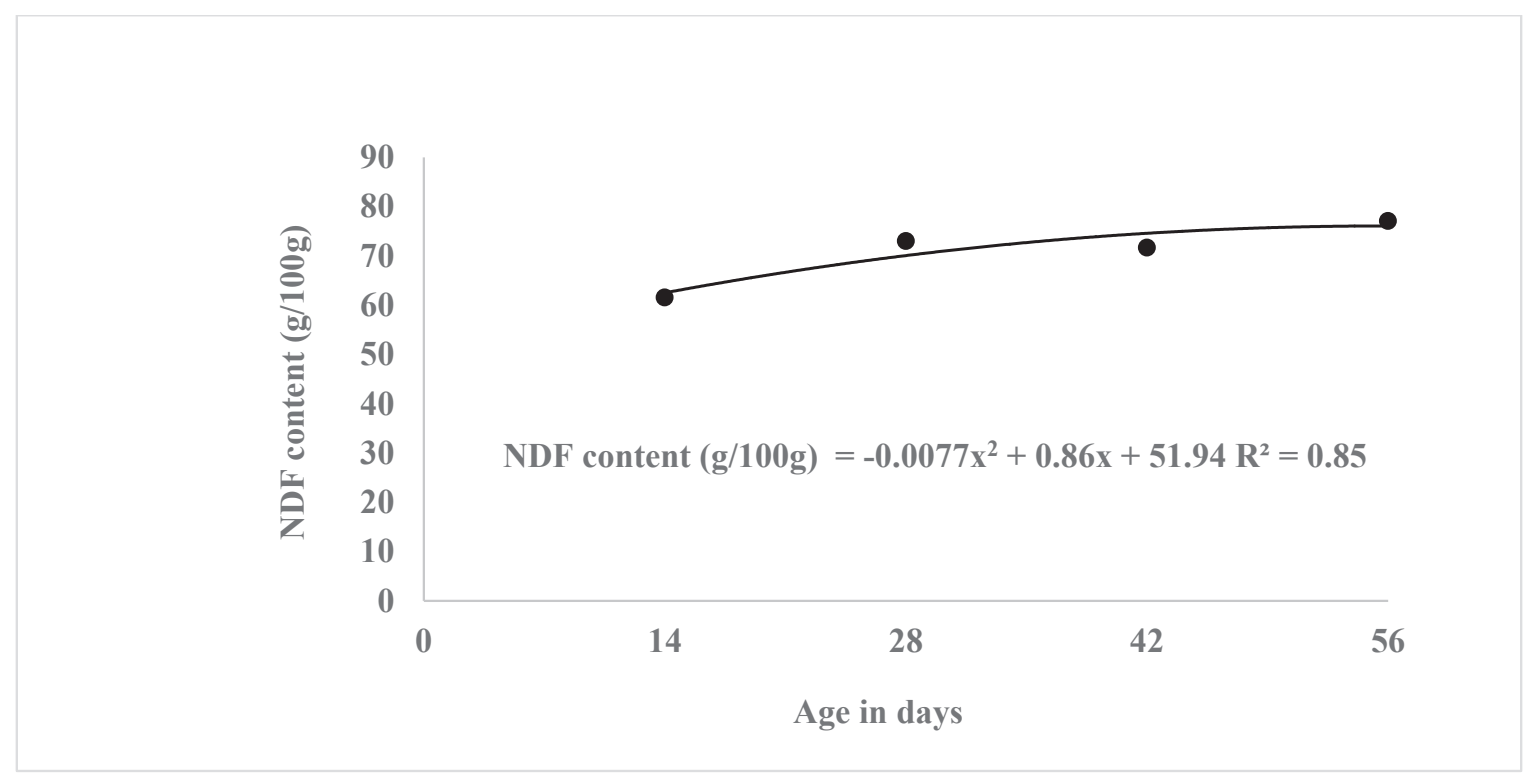

Figure 4. NDF content of Brachiaria humidicola cv. BRS Tupi. 
ADF content increased quadratically $(\mathrm{P}<0.05) \quad$ (Branco, Coneglian, Maia, \& Magalhães, 2006; and peaked at $55.84 \mathrm{~g} / 100 \mathrm{~g}$ at 56 days (Figure 5). Torres et al., 2016). Therefore, forage plants This variable is a major factor for feed digestibility harvested at more advanced ages will be less since, as ADF content increases in the forage plant, $\mathrm{DM}$ and organic matter digestibility decrease

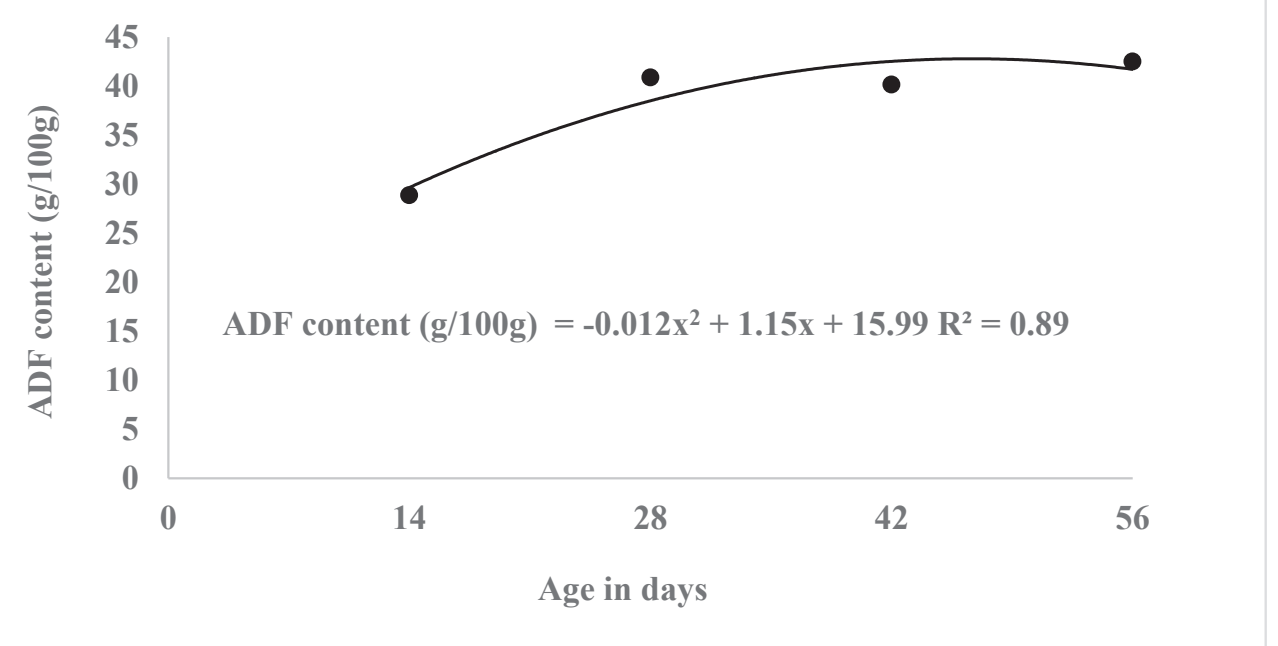

Figure 5. ADF content of Brachiaria humidicola cv. BRS Tupi.

Lignin concentration (Figure 6) increases and such effect is more pronounced as plant age quadratically $(\mathrm{P}<0.05)$ with harvest age and reached advances (Wilson \& Hatfield, 1997), forage plants a maximum of $5.72 \mathrm{~g} / 100 \mathrm{~g}$ at 50 days. Since lignin harvested at more advanced stages will likely be impacts the digestibility of cell wall components less degraded (Cezário et al., 2015).

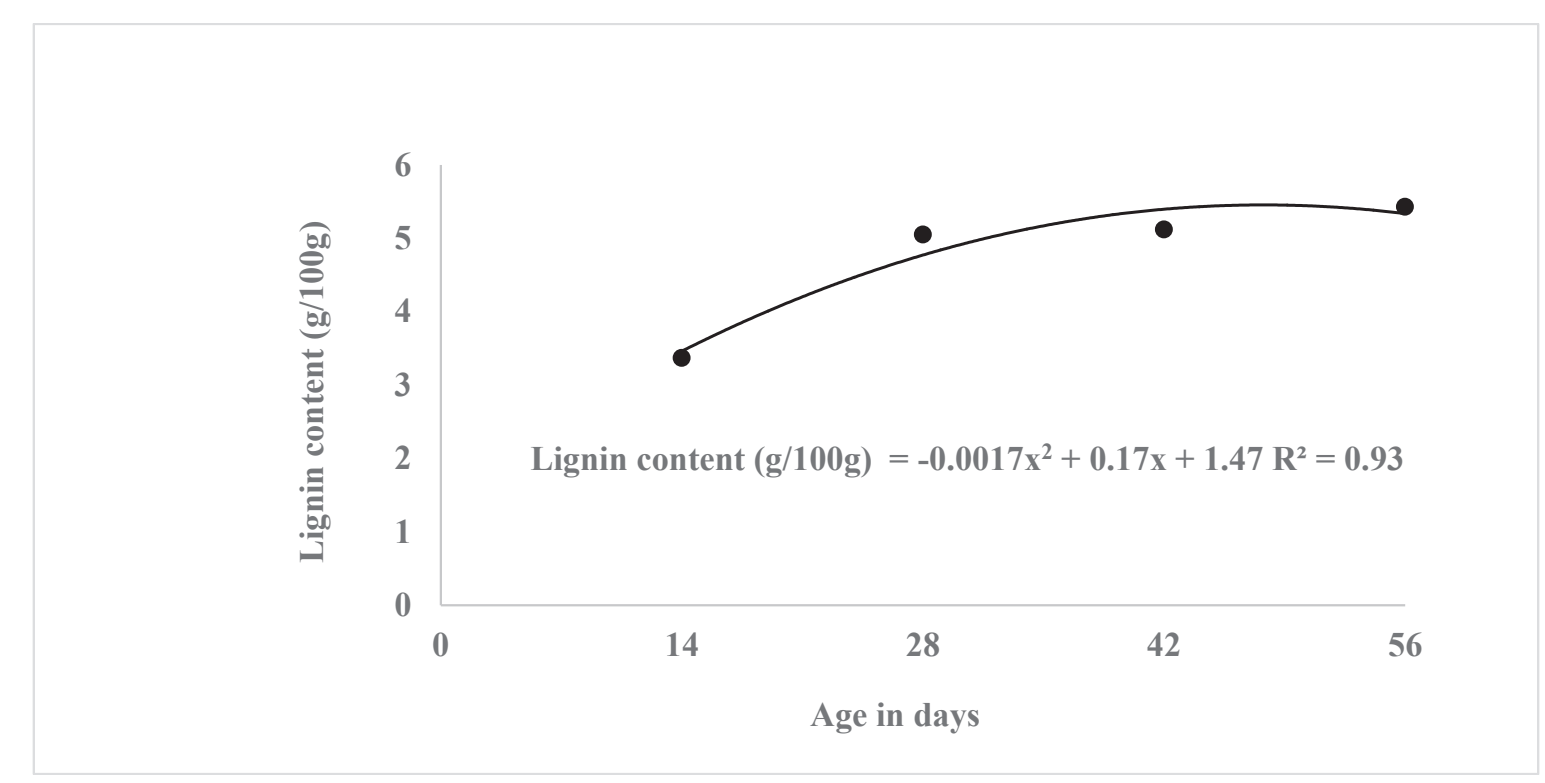

Figure 6. Lignin content of Brachiaria humidicola cv. BRS Tupi. 
The most significant changes in chemical composition of forage plants derive from their maturity since, as plants mature, the production of potentially digestible components tends to decrease and, consequently, the proportion of lignins, cellulose, hemicelluloses, and other non-digestible fractions increase, which reflects in overall lower digestibility (Cezário et al., 2015).

Cutting in intervals of 28 to 42 days led to longer leaf life span and desirable bromatological characteristics and are likely to lead grazing animals to high zootechnical performance.

\section{Conclusion}

In view of morphogenic and structural characteristics and bromatological composition, cutting intervals between 28 and 42 days for Brachiaria humidicola cv. BRS Tupi can be considered the most appropriate for forage potential in animal feed.

\section{References}

Associação para o Fomento à Pesquisa de Melhoramento de Forrageiras. (2019). Brachiaria humidicola. Brasília: Embrapa Gado de Corte. Retrieved from http://www.semembras.com.br/folders/brs-tupi.pdf

Association of Official Analytical Chemists. (1990). Official methods of analyses of the AOAC (15th ed.). Arlington: Virginia.

Branco, A. F., Coneglian, S. M., Maia, F. J., \& Guimarães, K. C. (2006). Digestibilidade intestinal verdadeira da proteína de alimentos para ruminantes. Revista Brasileira de Zootecnia, 35(4), 1788-1795. doi: 10.1590/S1516-35982006000600029

Camara, T. T. (2013). Morfogênese e estrutura de pasto de Brachiaria humidicola sob lotação contínua em diferentes intensidades de pastejo. Dissertação de mestrado, Universidade Estadual de Mato Grosso do Sul, Aquidauana, MT, Brasil.

Cezário, A. S., Ribeiro, K. G., Santos, S. A., Valadares, S. de C, $\mathrm{F}^{\circ}$, \& Pereira, O. G. (2015). Silages of Brachiaria brizantha cv. Marandu harvested at two regrowth ages: microbial inoculant responses in silage fermentation, ruminant digestion and beef cattle performance. Animal Feed Science and Technology, 208(2015), 33-43. doi: 10.1016/j. anifeedsci.2015.06.025

Chiari, L., Rocha, M., Valle, C. B., \& Salgado, L. R. (2008). Variabilidade genética em acessos e cultivares de quatro espécies de Brachiaria estimada por marcadores RAPD. Campo Grande: Embrapa Gado de Corte. Embrapa Gado de Corte. Boletim de Pesquisa e Desenvolvimento, 24.

Costa, K. A. P., Oliveira, I. P. de, Faquin, V., Neves, B. P. das, Rodrigues, C., \& Sampaio, F. D. M. T. (2007). Intervalo de corte na produção de massa seca e composição químico-bromatológica da Brachiaria brizantha cv. MG-5. Ciência Agrotecnica, 31(4), 1197-1202. doi: 10.1590/S141370542007000400037

Gomide, C. A. M., Gomide, J. A., \& Paciullo, D. S. C. (2006). Morfogênese como ferramenta para o manejo de pastagens. Anais da Reunião da sociedade Brasileira de Zootecnia, João Pessoa, PB, Brasil, 43. Retrieved from https://www.bdpa.cnptia.embrapa. br/consulta/

Jung, H. G., \& Allen, M. S. (1995). Characteristics of plant cell walls affecting intake and digestibility of forages by ruminants. Journal of Animal Science, 73(9), 2774-2790. doi: 10.2527/1995.7392774x

Leal, E. S., Ítavo, L. C. V., Valle, C. B. do, Ítavo, C. C. B. F., Dias, A. M., Barbosa-Ferreira, M.,... Ferreira, V. B. N. (2016). Anti-nutritional potential of protodioscin and kinetics of degradation in Urochloa grasses. Semina: Ciências Agrárias, 37(4), 22472257. doi: 10.5433/1679-0359.2016v37n4p2247

Maranhão, C. M. A., Bonomo, P., Pires, A. J. V., Costa, A. C. P. R., Martins, G. C. F., \& Cardoso, E. O. (2010). Características produtivas do capim-braquiária submetido a intervalos de cortes e adubação nitrogenada durante três estações. Acta Scientiarum. Animal Sciences, 32(4), 375-384. doi: 10.4025/ actascianimsci.v32i4.8574

Martins, C. D. M., Euclides, V. P. B., Barbosa, R. A., Montagner, D. B., \& Miqueloto, T. (2013). Consumo de forragem e desempenho animal em cultivares de Urochloa humidicola sob lotação contínua. Pesquisa Agropecuária Brasileira, 48(10),1402-1409. doi: 10.1590/S0100-204X2013001000012

Oliveira, M. A., Pereira, O. G., Gomide, J. A., Huaman, C. A. M., Garcia, R., \& Cecon, P. R. (2000). Análise do crescimento do capim-bermuda "Tifton $85^{\text {ce }}$ (Cynodon spp.). Revista Brasileira de Zootecnia, 29(6), 1930-1938. 
Sales, E. C. J., Reis, S. T. dos, Rocha, V. R., Jr., Monção, F. P., Matos, V. M., Pereira, D. A.,... Silva Antunes, A. P. da. (2014). Características morfogênicas e estruturais da Brachiaria brizantha cv. Marandu submetida a diferentes doses de nitrogênio e alturas de resíduos. Semina: Ciências Agrárias, 35(5), 26732684. doi: 10.5433/1679-0359.2014v35n5p2673

Santos, B. N. R., Sales, R. O., \& Costa, M. R. G. F. (2007). Teores de matéria seca e matéria mineral do feno de duas variedades de capim elefante sob quatro períodos de corte. Anais do Simpósio de Nutrição e Alimentação Animal, Fortaleza, Ceará, Brasil, 1. Recuperado de http://www.higieneanimal.ufc.br/ anais/anaisb/aa24_6.pdf

Silva, C. D., Bonomo, P., Pires, A. J. V., Maranhão, C. D. A., Patês, N. D. S., \& Santos, L. C. (2009). Características morfogênicas e estruturais de duas espécies de braquiária adubadas com diferentes doses de nitrogênio. Revista Brasileira de Zootecnia, 38(4), 657-661. doi: 10.1590/S1516-35982009000400010

Silva, E. M., Andrade, A. C., Magalhães, J. A., Rodrigues, B. H. N., Oliveira, A. B. B., Santos, F. J. de S.,... Bezerra, E. E. A. (2015). Características morfogênicas da Brachiaria brizantha cv. Marandu submetida a doses de nitrogênio. PUBVET, 9(6), 252-286.

Silveira, M. C. T. (2006). Caracterização morfogênica de oito cultivares do gênero Brachiaria e dois do gênero Panicum. Dissertação (Mestrado) - Universidade Federal de Viçosa, Viçosa, MG, Brasil.
Torres, F. E., Valle, C. B. do, Lempp, B., Teodoro, P. E., Santos, A. dos, \& Ribeiro, L. P. (2016). Contribuição dos caracteres de qualidade da forragem ao teor de proteína bruta em Urochloa brizantha. Pesquisa Agropecuária Brasileira, 51(3), 284-287. doi: 10.1590/S0100-204X2016000300011

Valle, C. B., Jank, L., \& Resende, R. M. S. (2009). O melhoramento de forrageiras tropicais no Brasil. Revista Ceres, 56(4), 460-472.

Valle, C. B., Macedo, M. C. M., Euclides, V. P. B., Jank, L., \& Resende, R. M. S. (2010). Gênero Brachiaria. In Fonseca, D. M.; Martuscello, J. A. (Org.). Plantas forrageiras (Chap. x, pp. 30-77). Viçosa: Editora UFV.

Van Soest, P. J. (1994) Nutritional ecology of the ruminant (2th ed.). Ithaca: Cornell University Press.

Van Soest, P. V., Robertson, J. B., \& Lewis, B. A. (1991). Methods for dietary fiber, neutral detergent fiber, and nonstarch polysaccharides in relation to animal nutrition. Journal of Dairy Science, 74(10), 35833597. doi: 10.3168/jds.S0022-0302(91)78551-2

Wilson, J. R., \& Hatfield, R. D. (1997). Structural and chemical changes of cell wall types during stem development: consequences for fibre degradation by rumen microflora. Australian Journal of Agricultural Research, 48(2), 165-180. doi: 10.1071/A96051 
